Yayınlayan: Ankara Üniversitesi KASAUM

Adres: Kadın Sorunları Araştırma ve Uygulama Merkezi, Cebeci 06590 Ankara

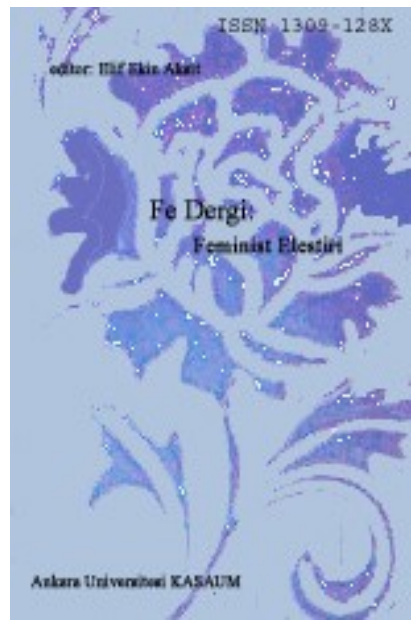

Fe Dergi: Feminist Eleştiri 12, Sayı 2

Erişim bilgileri, makale sunumu ve ayrıntılar için:

http://cins.ankara.edu.tr/

Kadın Psikolojik Gü̧̈ Ölçeği: Ölçek Geliştirme Çalışması

Binaz Bozkur

Çevrimiçi yayına başlama tarihi: 20 Aralık 2020

Yazı Gönderim Tarihi: 22.09.2020

Yazı Kabul Tarihi: 24.11.2020

Bu makaleyi alıntılamak için: Binaz Bozkur, "Kadın Psikolojik Güç Ölçeği: Ölçek Geliştirme Çalışması" Fe Dergi 12, no. 2 (2020), 15-31.

URL: http://cins.ankara.edu.tr/24_2.pdf

$\mathrm{Bu}$ eser akademik faaliyetlerde ve referans verilerek kullanılabilir. Hiçbir şekilde izin alınmaksızın çoğaltılamaz. 


\section{Kadın Psikolojik Güç Ölçeği: Ölçek Geliştirme Çalışması*} Binaz Bozkur*

Kadınların güçlendirilmesi konusu önemi gittikçe artan bir konudur. Kadının güçlendirilmesi sosyal, ekonomik, kültürel, politik, yasal ve psikolojik birçok boyutu kapsamaktadır. Psikolojik güç ise diğer bütün güç alanlarını etkileme potansiyeli olan bir alandır. Bu çalışmanın amacı kadınlarda psikolojik güçlenmeyi ölçecek Türkçe geçerli ve güvenilir bir ölçme aracının geliştirilmesidir. Geliştirilen ölçme aracının genel olarak kadınlardaki psikolojik güçlülüğü veya gücün artmasına ihtiyaç duyulan alanları belirlemesi hedeflenmektedir. Bu araştırma tarama modelinde yapılan bir ölçek geliştirme çalışmasıdır. Araştırmanın çalışma gruplarını yaşları 18-53 arasında değişen 1010 kadın oluşturmaktadır. Yapılan analizler sonucunda dört alt boyut (Güçlülük/Savunuculuk, Benlik Saygısı, Eğitime Yaklaşım, Kısıtlayıcılık) ve 34 maddeden oluşan bir yapı ortaya çıkmıştır. Ölçekten alınan yüksek puan kadının psikolojik güç algısının yüksek olduğunu göstermektedir. Yapılan analizler sonucunda geliştirilen ölçeğin geçerli ve güvenilir bir ölçme aracı olduğu ve çalışmalarda kullanılabileceği düşünülmektedir.

Anahtar Kelimeler: Toplumsal cinsiyet, kadının güçlendirilmesi, psikolojik güçlendirme, ölçek geliştirme

\section{Women's Psychological Empowerment Scale: A Scale Development Study}

The issue of women empowerment is an increasingly important issue. Women's empowerment encompasses many social, economic, cultural, political, legal and psychological dimensions. Psychological power is a field that has the potential to affect all other power fields. The aim of this study is to develop a valid and reliable Turkish measurement tool to measure psychological empowerment in women. The measurement tool developed is aimed to determine the psychological strength of women or the areas in which power is needed to be increased. This research is a scale development study conducted in a scanning model. The study groups of the research consist of 1010 women aged between 18-53. As a result of the analysis, a structure consisting of 4 sub-dimensions (Strength / Advocacy, Self-esteem, Approach to Education, Restriction) and 34 items emerged. High scores from the scale indicate that the woman has a high perception of psychological power. The scale developed as a result of the analysis is considered to be a valid and reliable measurement tool and can be used in future studies.

Keywords: Gender, women empowerment, psychological empowerment, scale development

\section{Giriş}

Kadınlarda güç ve güçlendirme kavramları sosyal, ekonomik, politik ve psikolojik açıdan önem kazanan ve tartışılan kavramlardır. Bu kavramların önem kazanmasının ve tartışılmasının nedeni temelde kadın ve erkek arasında eşit olmayan güç ilişkilerini görünür kılan toplumsal cinsiyet eşitsizliğine yönelik artan bilinç ve farkındalıklardır. Hiyerarşik toplumsal cinsiyet yapısının özellikle kadınlar için ortaya çıkan olumsuz etkilerini azaltmak ve/ veya ortadan kaldırmak amacıyla kadının güçlenmesi önem kazanmaktadır.

İnsanlar kendi kendine güçlenmez veya güçsüzleştirilmez. Güçlenme veya güçsüzleşme bireylerin içinde yaşadıkları toplumsal gruplarla veya temasta oldukları diğer insanlarla bağlantılı olarak gelişen bir süreçtir (Mason, 2003). Dolayısıyla kadının güçsüzleştirilmesi ve güçlenme ihtiyacının ortaya çıkması toplumsal cinsiyet eşitsizliği ile ilgilidir. Toplumsal cinsiyet kavramı ekonomik, politik ve kültürel kaynakların ve gücün eşit olmayan bir şekilde dağıtıldığı yapısal ve sosyal bir ilişkiye işaret eder (Lorber, 1994). Feminist düşüncenin etkisiyle kadınların güçlendirilmesi toplumsal, ekonomik ve demografik değişimin yanı sıra toplumsal cinsiyet

\footnotetext{
*Bu çalışmadaki verilerin bir kısmı, 10 Eylül - 13 Eylül 2020 Tarihinde yapılan 7.Uluslararası Avrasya Eğitim Araştırmaları Kongresi'nde sözlü bildiri olarak sunulmuștur.

*Dr., Mersin Üniversitesi, Eğitim Fakültesi, Rehberlik ve Psikolojik Danışmanlık Bölümü, Orcid:0000-0002-3821-7489, b.bozkur@hotmail.com, Yazı Gönderim Tarihi: 22.09.2020, Yazı Kabul Tarihi: 24.11.2020
} 
eşitliğini sağlamada da önemli bir faktör olarak kabul edilmektedir (Pradhan, 2003). Yani kadının güçlendirilmesi kendi başına bir amaç değil, toplumsal cinsiyet eşitliğini sağlama yolunda çok önemli bir adımdır (Murphy-Graham, 2010). Bu adımın anlaşılması için ilk etapta güçlendirme kavramının açıklanmasına ihtiyaç duyulmaktadır.

Genel olarak güçlendirme bireyin özerk bir şekilde düşünmesini, harekete geçmesini ve işi kontrol etmesini sağlamasını; ayrıca kişinin kaderi ve yaşam koşulları üzerinde kontrol sahibi olabilmesini sağlayan bir süreçtir (Bhat, 2015). Güçlenme hem kaynaklar (fiziksel, entelektüel, ekonomik) hem de ideoloji (inançlar, değerler ve tutumlar) üzerindeki kontrolü içerir. Kişinin öz güveni ve bilincini kullanarak kaynaklara erişme veya geleneksel ideolojiyi değiştirme önündeki dış engellerin üstesinden gelmesini sağlayan içsel bir dönüşüm anlamına gelir (Sen ve Batliwala, 2000). Yani güçlenme bireylerin tam potansiyellerine ulaşmalarını, siyasi ve sosyal katılımlarını iyileştirmelerini ve kendi yeteneklerine inanmalarını sağlayan bir süreçtir (Bhat, 2015). Güçlenmiş bireyler ise, yüksek benlik saygısına sahip, öz-yeterlik duyguları, yaşamları üzerindeki kontrol duyguları, eleştirel farkındalıkları ve sivil katılımları artmış bireyler olarak tanımlanmaktadır (Francina ve Joseph, 2013).

Kadınların güçlendirilmesi uluslararası bir konu olarak gündemde yer almaktadır. Birleşmiş Milletler Kadınlar Kalkınma Fonu'na (UNIFEM) göre, kadınların güçlendirilmesi aşağıdaki konuları içermektedir (UNIFEM, 2000):

1. Toplumsal cinsiyet ilişkileri ve bu ilişkilerin nasıl değiştirilebileceği hakkında bilgi ve anlayış kazanmak,

2. Kadınların öz değer duygusu geliştirmeleri, hayatlarında istedikleri değişimleri yaratma ve koruma yeteneğine ve hayatını kontrol etme hakkına inanmak,

3. Seçimler yapma becerisi kazanmak

4. Toplumsal değişimin yönünü örgütleme ve etkileme, ulusal ve uluslararası düzeyde daha adil bir sosyal ve ekonomik düzen oluşturma becerisini geliştirmek.

Kadınların güçlenmesinin/güçlendirilmesinin kapsamının oldukça geniş olduğu bilinmektedir. Kadının güçlendirilmesi sosyal, ekonomik, kültürel, politik, yasal ve psikolojik birçok boyutu kapsamaktadır (Malhotra ve ark. 2002). Güçlendirme, kadınların yaşamın her alanında kimliklerini ve güçlerini ortaya koymalarını sağlayan aktif ve çok boyutlu bir süreçtir (Pillai, 1995 ). Güçlendirmenin çeşitli bileşenleri literatürde de tartışılmaktadır. Örneğin Stromquist (1995) güçlendirmenin dört boyuttan oluştuğunu ve bu dört boyutun her birinin eşit öneme sahip olduğunu ancak hiçbirinin tek başına kadınların kendi adlarına hareket etmelerine olanak sağlamak için yeterli olmadığını belirtmektedir. Bu boyutlar bilişsel (kişinin kendi gerçekliğini eleştirel bir biçimde anlaması) psikolojik (özsayg1-benlik saygısı), politik (güç eşitsizliklerinin farkında olma ve örgütlenme ile harekete geçme yetisi) ve ekonomik (bağımsız gelir oluşturma kapasitesi) boyutlarıdır. Huis, Hansen, Otten ve Lensink (2017) kadınların güçlendirilmesinin üç farklı boyutta gerçekleşebileceğini önermektedirler. Bunlar: (1) bireyin kişisel inançları ve kişisel güçlenmenin gözlemlenebileceği eylemleri içeren mikro düzey, (2) bireyin çevresindeki diğer insanlarla ilişkilerdeki güçlenmesini içeren mezo düzey (3) toplumsal güçlenmenin gözlemlenebileceği daha geniş, toplumsal bağlamdaki güçlenmeye dair çalışmaları içeren makro düzey güçlenmeye işaret etmektedir. Kawaguchi ve ark. (2014) ise kadınlarda güçlenmenin bileşenlerini hareket özgürlüğü, ekonomik güvenlik ve istikrar, aile desteği, tahakkümden kurtulma, günlük yaşamda karar verme ve toplumsal katılım olarak ifade etmişlerdir. Güçlendirmenin içeriği daha çok karar verme, seçim yapma ve ekonomik güce vurgu yapsa da bu içerikleri sağlamak için psikolojik güçlenme ön koşul olarak düşünülmektedir.

Genel güçlendirmeden farklı olarak psikolojik güçlendirme kişisel etkinliği sağlamak veya arttırmak olarak tanımlanmaktadır (Conger ve Kanungo, 1988). Psikolojik güçlenmeye benzer olarak kişisel güçlenme ise Rowlands (1997) tarafından özgüven, benlik saygısı, kontrol duygusu, daha geniş bir bağlamda benlik algısı ve onuru güçlendirmeye destek olan dönüşüm süreçlerinin temelini oluşturan temel öğeler kümesi olarak tanımlamıştır. Kişisel güçlenmenin özü ise kadının kültürden veya bağlamdan kaynaklanan toplumsal cinsiyet rollerinden çıkabilmesidir (Francina ve Joseph, 2013). Bu konuda bilinç kazanma ve güçlenmede eğitimin önemli bir işlevi vardır.

Eğitim, kadınların güçlenmesinde ve toplumdaki konumlarını değiştirebilmesinde rol oynayan araçlardan en güçlüsüdür. Eğitimsel düzenlemeler kadınlarda bilişsel, psikolojik, politik ve ekonomik boyutlarda 
güçlenmeyi geliştirme potansiyeline sahiptir. Ancak eğitimin kadınların toplumsal potansiyelini sınırlandıran, erkeklik ve kadınlıkla ilgili cinsiyetçi kalıp yargılara karşı koyma ve sorgulamayı mümkün kılacak bilgi ve becerileri geliştirmede kadınlara olanak sağlayan bir içerikte olması gerekmektedir (Stromquist, 2012). Yani eğitim her ne kadar zaman zaman toplumsal cinsiyet rollerini yeniden üretme riski barındırsa da kadınların güçlenmesinde önemli bir faktördür ve eğitimin kadınlar için öneminin farkında olmak da bu çerçevede kadının güçlenmesinin önemli bir adımıdır.

Kadınlarda güçlenmenin ölçülmesi de güçlenme/güçlendirme kavramına bağlı olarak çok boyutlu ve karmaşık bir yapı sergilemektedir. Kadınlarda güçlenmeyi ölçmede sosyo-demografik değişkenler (yaşam süresi, ilk evlilik yaşı, doğum yaşı, gebelik sayısı, doğurganlık yaşı vb.), sağlık ile ilişkili değişkenler (anne ve bebek ölüm oranları, kadının fiziksel ve cinsel şiddete maruz kalma oranı, kadın sünneti oranı, doğum kontrolü, vb.), eğitim ile ilgili değişkenler (okur yazarlık oranları, eğitime erişme/okullaşma oranları, eğitim sisteminde kalma süreleri, vb.), ekonomik haklar (iş gücüne katılım oranı, ücret durumları, işsizlik oranları, profesyonel işlerde çalışma oranları, vb.), siyasi katılım ve haklar ile ilgili değişkenler (parlamentodaki kadın oranları, kabinedeki kadın sayısı, bakanlıkların altında yer alan üstü düzey siyasi pozisyonlardaki kadın oranları, yasa yapıcı kurumlarda kadın oranı ve kurumların üst düzey yetkilileri ve yöneticileri arasındaki kadın oranları, vb.) ve kültürel katılım ve haklar ile ilgili değişkenler (bilgisayar ve internete erişim oranları, kadınlara ait sivil toplum kuruluşları, kadınların sesini duyuran medya mecralarının sayısı, güzel sanatlar, sosyal ve beceri bilimlerde okuyan kadın öğrenci oranları, müze personellerindeki kadın oranları, kültür bakanlığında karar alma mercilerinde kadınların bulunma oranı, vs.) çerçevesinde değerlendirilebileceği savunulmuştur (Moghadam ve Senftova, 2005). Bu yaklaşım belli bir dereceye kadar doğru olabilir ancak kadınların güçlenmesi ve statülerindeki ilerleme geleneksel sosyo-ekonomik değişkenlerinin ötesine geçmeyi gerektirmektedir (Pradhan, 2003). Bu durum ise psikolojik güçlenmenin önemini ortaya koymaktadır.

Kişinin kendi durumunu değiştirebileceği inancı ve değişimi hedefleyen faaliyetlere katılma isteği olmadığı sürece kişinin güçlenmesi mümkün değildir. Bu nedenle psikolojik güçlendirmedeki eksikliğinin diğer tüm güçlendirme biçimlerinin etkisini kıracağı açıktır (Francina ve Joseph, 2013). Kadınlarda psikolojik güçlenmenin ölçülmesi için geçerli ve güvenilir ölçme araçlarına ihtiyaç duyulmaktadır. Literatür incelendiğinde İran'daki sivil toplum kuruluşlarındaki kadınlar için geliştirilen "Psikolojik Güçlendirme Ölçeği” sadece sivil toplum kuruluşlarındaki kadınlarda psikolojik güçlenmeyi (Bakshi ve ark.), Spreitzer (1995) tarafından geliştirilen ve Türkçe'ye Üner ve Turan (2010) tarafından uyarlanan “Psikolojik Güçlendirme Ölçeği” ise sadece çalışma ortamlarındaki psikolojik güçlülüğü ölçen bir araçtır. Schuler, Hashemi ve Riley (1997) tarafından geliştirilen ve Baydur ve Uçan (2016) tarafından Türkçe'ye uyarlanan "Kadının Güçlendirilmesi Ölçeği”" ise kadınların gündelik yaşam deneyiminden yola çıkarak davranışları aracılığıyla hangi alanlarda güçlendirilmeleri gerektiğini tespit etmeyi amaçlayan bir ölçme aracıdır (Baydur ve Uçan, 2016). Bu ölçek incelendiğinde ise daha çok sosyal ve ekonomik açıdan kadının gücünü ölçmeyi amaçladığı gözlenmiştir. Alan yazında yer alan ölçekler incelendiğinde kadınlarda psikolojik güçlenmeyi ölçen dili Türkçe olan, geçerli ve güvenilir bir araca rastlanmamıştır. Bu çerçevede kadınlarda bütün gücü etkileme potansiyeline sahip olan psikolojik gücü ölçmekte kullanılabilecek nitelikte geçerli, güvenilir ve kullanışlı bir ölçme aracına ihtiyaç duyulmaktadır. Bu nedenle bu çalışmanın amacı kadınlarda psikolojik güçlenmeyi ölçecek Türkçe geçerli ve güvenilir bir ölçme aracının geliştirilmesidir.

Araştırmada geliştirilen ölçme aracının yapısı oluşturulurken genel olarak kadınların öz güveni ve bilinci kullanarak kaynaklara erişme veya geleneksel ideolojiyi değiştirme önündeki dış engellerin üstesinden gelmesini sağlayan içsel bir dönüşüm anlamına gelen güçlenme/güçlendirme (Sen ve Batliwala, 2000) tanımı dikkate alınmıştır. Güçlenmenin psikolojik yönüne odaklanan ölçme aracının içeriğine karar verilirken psikolojik güçlenmenin özünün kadının kültürden veya bağlamdan kaynaklanan toplumsal cinsiyet rollerinden çıkabilmesi (Francina ve Joseph, 2013) olduğu ve bileşenlerinin özgüven, benlik saygısı, kontrol duygusu, benlik algisı ve onuru güçlendirmeye destek olan dönüştürücü süreçler (Rowlands, 1997) olarak belirtildiği dikkate alınmıştır. Eğitimin kadınların toplumdaki konumlarını değiştirmenin en güçlü yollarından biri olduğu ve kadınlarda bilişsel, psikolojik, politik ve ekonomik boyutlarda güçlenmeyi geliştirme potansiyeline sahip olduğu (Stromquist, 2012) göz önünde bulundurularak geliştirilen ölçme aracında eğitime yaklaşımı ölçen maddelerin olması gerektiğine karar verilmiştir. Bu çerçevede geliştirilen ölçme aracının kadının kültürden veya bağlamdan kaynaklanan geleneksel toplumsal cinsiyet rollerine karşı çıkma, özgüven, kadın olarak benlik saygısı, kadının statüsünde eğitimin etkisine yönelik bilinç ve genel olarak kadının kendi psikolojik gücüne yönelik algısını 
ölçmesi planlanmaktadır. Geliştirilen ölçme aracının genel olarak kadınlardaki psikolojik güçlülüğü veya gücün artmasına ihtiyaç duyulan alanları belirlemesi hedeflenmektedir.

\section{Yöntem}

$\mathrm{Bu}$ araştırma tarama modelinde yapılan bir ölçek geliştirme çalışmasıdır. Araştırma, nicel bir araştırma olup temel araştırma niteliğindedir.

\section{Çalışma Grupları}

Araştırmada üç çalışma grubundan veri toplanmıştır. Birinci çalışma grubu yaşları 18 ile 53 arasında değişen 500 kadından oluşmaktadır. Yapılan analizde uç değer oldukları tespit edilen 27 veri analiz kapsamından çıkartılmıştır. Analizler 473 veri üzerinden yürütülmüştür. Bu kadınların \%70,8’i lisans ve lisansüstü eğitim düzeyine \%29,2'si ise lise ve altı eğitim düzeyindedir. Bu çalışma grubundan geliştirilen ölçeğin yapı geçerliliği ve Cronbach Alpha iç tutarlılık katsayısının hesaplanması için veri toplanmıştır. İkinci çalışma grubu da yaşları 18 ile 53 arasında değişen 443 kadından oluşmaktadır. Bu kadınların \%53,8'i lisans ve lisansüstü eğitim düzeyinde \%46,2'si ise lise ve altı eğitim düzeyindedir. İkinci çalışma grubundan ise ilk analizde ortaya çıkan yapının doğrulayıcı faktör analizi ile test edilmesi için veri toplanmıştır. Araştırmanın üçüncü çalışma grubu ise yaşları 18-22 arasında değişen 67 üniversite öğrencisi genç kadından oluşmaktadır. Bu gruptan test-tekrar test güvenirliği için veri toplanmıştır. Test-tekrar test yapılabilmesi için bu grup tekrar ulaşılabilmesi amacıyla üniversite öğrencilerinden seçilmiştir.

\section{İşlem}

Araştırma kapsamında toplanan veriler Google form aracılığıyla, katılımcılara telefon ve elektronik posta ile ulaşılarak toplanmıştır. Veri toplama sürecinde gönüllülük esas alınmıştır.

\section{Verilerin Analizi}

Verilerin analizinde ilk önce verilerin faktör analizine uygun olup olmadığı belirlenmiştir. Verilerin faktör analizine uygun olup olmadığını incelemek için Kaiser- Meyer- Olkin (KMO) katsayısının .60'tan yüksek ve Bartlett testinin anlamlı çıkması ölçütü aranmaktadır (Büyüköztürk, 2010). Yapılan analizde KMO değerinin . 83,6 ve Bartlett küresellik testinin anlamlı olduğu görülmüştür $\left(X^{2}=3954,55 \mathrm{df}=465, \mathrm{p}<.00\right)$. KMO değerinin . 83,6 olması örneklem büyüklüğünün faktör analizi için yeterli olduğunu göstermektedir. Bartlett testinin anlamlı olması ise verilerin normal dağılımının kanıtı olarak görülmektedir (Büyüköztürk, 2010). Verilerin faktör analizine uygun olduğu göz önünde bulundurularak Açımlayıcı Faktör Analizi (AFA) tekniğinden yararlanılmıştır. Ölçeğin ortaya çıkan yapısının doğrulanması için ise birinci ve ikinci düzey Doğrulayıcı Faktör Analizi (DFA) tekniğinden yararlanılmıştır. Birinci düzey DFA ölçeğin AFA ile ortaya çıkan 4 faktörlü yapısını doğrulamak için yapılmıştır. Çeşitli boyutları olan bir yapıyı ortak bir üst düzey faktörünün altına toplayarak yorumlama tekniği olan ikinci düzey DFA (Gould, 1987) ise ortaya çıkan alt boyutların Kadın Psikolojik Güç Ölçeği’nin bileşenleri olup olmadığını belirlemek için kullanılmıştır. Ölçeğin güvenirlik analizi için Cronbach Alpha İç Tutarlılık Katsayısı, test-tekrar test ve ölçeğin alt boyutlarının birbirleri ve ölçek toplam puanıyla ilişkilerinin incelenmesi için ise Pearson Momentler Çarpımı Korelasyon Katsayısı tekniğinden yararlanılmıştır.

\section{Bulgular}

Ölçek geliştirme sürecinde ölçeğin geçerlik ve güvenirlik hesaplamaları için kapsam geçerliliği, yapı geçerliliğii, Cronbach Alpha iç tutarlılık katsayısı, test-tekrar test güvenirliği çalışmaları yapılmıştır.

\section{Ölçeğin Geçerliliği}

Ölçeğin geçerliliğini test etmek için kapsam geçerliliği ve yapı geçerliği incelenmiştir. Elde edilen bulgular aşağıda sunulmuştur.

\section{Kapsam Geçerliliği}

Ölçeğin madde havuzu hazırlanırken ilk etapta güçlendirmenin bileşenlerinin neler olduğu incelenmiş ve bu konudaki alan yazın ile uyumlu olarak kadınlarda güçlenmeyi ölçebileceği düşünülen 34 madde yazılmıştır. Hazırlanan maddeleri içeren bir uzman görüş formu oluşturulmuş ve bu maddeler ile ilgili 3'ü Ölçme ve 
Değerlendirme, 4'ü Psikolojik Danışma ve Rehberlik alanından toplam 7 uzmandan görüş istenmiştir. Uzmanlardan maddeleri 1 (hiç uygun değil) ile 4 (çok uygun) arasında puanlamaları ve varsa düzeltmeye ilişkin önerilerini yazmaları istenmiştir. Hazırlanan maddelere uzmanların verdikleri yanıtlar üzerinden kapsam geçerlik indeksleri hesaplanmıştır. Yapılan kapsam geçerliliği analizinde uzmanlar tarafından uygun görülmeyen (kapsam geçerliliği indeksi .41-.65 arasında değişen )10 madde uzmanların önerilerine uygun bir biçimde revize edilmiştir. Uzmanların önerdiği 4 madde de forma eklenmiştir. Yapılan analiz sonucunda 38 maddelik deneme formu oluşturulmuştur. Hazırlanan deneme formu 25 kişilik bir gruba uygulanarak ifadelerin anlaşılır olup olmadığı sınanmıştır. Pilot uygulamadan elde edilen geri bildirimlerle uygulama formunun son hali oluşturulmuştur.

\section{Yapı Geçerliliği}

Ölçeğin yapı geçerliliğinin test edilmesi amacıyla Açımlayıcı Faktör Analizi (AFA) ve Doğrulayıcı Faktör Analizi (DFA) tekniklerinden yararlanılmıştır.

\section{Açımlayıcı Faktör Analizi}

AFA için önerilen örneklem büyüklüğünün en az 300 kişi olması ve ölçekte bulunan her madde için gözlem sayısının 5 ile 10 kişi arasında olması gerektiği belirtilmektedir (Tabachnick ve Fidell, 2001). AFA'da örneklem büyüklüğüyle ilgili olarak Comrey ve Lee (1992) ise 100 sayısının az 200 sayısının orta; 300 sayısının iyi; 500 sayısının çok iyi; 1000 gözlem ve daha fazlasının ise mükemmel olduğunu belirtmişlerdir. Gözlem sayısının 473 ve madde sayısının 34 olduğu göz önünde bulundurulduğunda gözlem sayısının madde sayısının 10 katından fazla ve 300'ün üzerinde olmasının ise örneklem büyüklüğünün iyi kategorisinde değerlendirilebileceği düşünülmektedir.

Yapılan ilk faktör analizi sonucunda özdeğeri 1'in üzerinde olan 9 faktörün olduğu gözlenmiştir ancak faktör sayısına karar vermek için Scree Plot grafiği incelenmiştir.

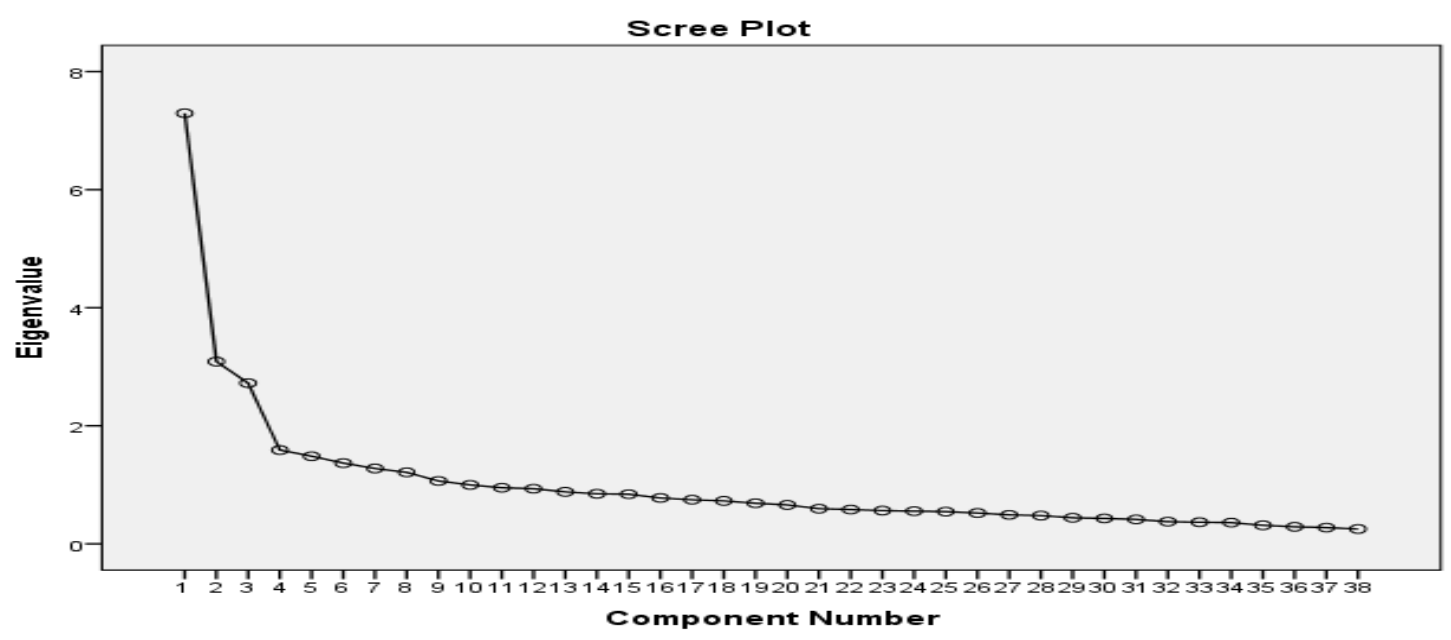

Grafik 1. Scree Plot Grafiği

Scree Plot grafiği incelendiğinde 38 maddelik Kadın Psikolojik Güç Ölçeğinin 4. boyuttan sonra yatay eksene paralel bir görünüm sergilediği gözlenmektedir. $\mathrm{Bu}$ durum ölçeğin 4 faktörlü olduğunu düşündürtmektedir. Bunun üzerine faktör sayısı 4'e sabitlenerek tekrar faktör analizi yapılmıştır.

Eğik veya dik döndürme kararı verilirken faktörlerin ilişkili olup olmadığının incelenmesi gerekmektedir. Eğer faktörler ilişkisizse dik döndürme; ilişkiliyse eğik döndürme kullanılmalıdır (Tabachnick ve Fidel, 2001). Bunun için önce eğik döndürme (Direct Oblimin) yapılarak 4 faktörün birbiriyle korelasyonları incelenmiştir. Yapılan analizde faktörler arasındaki korelasyonun .30'un altında ve $p<0,05$ düzeyinde anlamlı olmadığı gözlenmiştir. Bu nedenle analizde döndürme tekniği olarak Varimax dik döndürme kullanılmıştır.

Genel olarak faktör yük değerinin işaretine bakılmaksızın faktör yük değerlerinin 0.30-0.59 arası olması orta düzey, 0.60 ve üstü olması ise yüksek düzey ilişki olduğuna işaret etmektedir (Büyüköztürk, 2010). Stevens 
(2002) ise faktör yük değerleri arasındaki farkın minimum .10 olması gerektiğini belirtmektedir. Bu temelde yapılan analizde öncelikle faktör yük değerleri .30'dan düşük olan maddeler ve faktör yük değerleri farklı boyutta birbirine yakın olan (aralarındaki fark .10 ve daha düşük olan maddeler) 7 madde ölçekten çıkarılmıştır. Ölçekte kalan maddeler ile yapılan son faktör analizindeki faktör yüklerine ait bulgular Tablo 1'de sunulmuştur.

Tablo 1. Kadın Psikolojik Güç Ölçeği’ne ait Maddelerin Faktör Yükleri

\begin{tabular}{|c|c|c|c|c|}
\hline Madde & $\begin{array}{l}\text { Faktör } \\
1\end{array}$ & $\begin{array}{l}\text { Faktör } \\
2\end{array}$ & $\begin{array}{l}\text { Faktör } \\
3\end{array}$ & $\begin{array}{l}\text { Faktör } \\
4\end{array}$ \\
\hline 1. Bir kadın olarak yeteneklerime güvenirim. &, 735 & & & \\
\hline 2. Diğer kadınları yasal haklarını kullanmaları için teşvik ederim. & ,638 & & & \\
\hline 3. Bir kadın olarak güçlü yönlerimin farkındayım. & ,629 & & & \\
\hline $\begin{array}{l}\text { 10. Etrafımdaki kadınları eğitimlerine devam etmeleri için } \\
\text { cesaretlendiririm. }\end{array}$ & ,617 & & & \\
\hline 11. Kendimi en az erkekler kadar değerli bulurum. & ,562 & & & \\
\hline $\begin{array}{l}\text { 12. Hangi sorunlarla karşılaşırsam karşılaşayım eğitimime devam } \\
\text { etmeye önem veririm. }\end{array}$ & 557 & & & \\
\hline $\begin{array}{l}\text { 17. Zihinsel beceri gerektiren bütün işleri en az erkeklerin } \\
\text { yapabildiği kadar iyi yapabilirim. }\end{array}$ & 557 & & & \\
\hline $\begin{array}{l}\text { 18. Kadına yönelik şiddet, baskı vb. olumsuzluklarla mücadele } \\
\text { edilmesini teşvik ederim }\end{array}$ & 5,554 & & & \\
\hline $\begin{array}{l}\text { 19. Eğitim kadının statüsünü olumlu yönde değiştiren en önemli } \\
\text { araçtır. }\end{array}$ &, 511 & & & \\
\hline 23. Hayatımdaki önemli insanlarla eşit ilişkiler kurarım &, 510 & & & \\
\hline 24. Kadın olarak yasal haklarımın farkındayım. &, 450 & & & \\
\hline 26. Verdiğim kararlar iyi sonuçlanır. & ,423 & & & \\
\hline 27. Eğitimli kadın karşı cinsle daha eşit ilişkiler kurabilir. &, 351 & & & \\
\hline $\begin{array}{l}29 . \text { Kadına yönelik şiddet davalarında daha ağır cezalar } \\
\text { verilmelidir. }\end{array}$ & ,309 & & & \\
\hline 4.Verdiğim kararların saçma bulunmasından korkarım. & 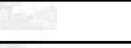 & ,641 & & \\
\hline 5. Diğer insanların benden hoşlanmamalarından korkarım. & & ,639 & & \\
\hline 6. Karar verirken zorlanırım. & & 619 & & \\
\hline $\begin{array}{l}\text { 13. Bir kadın olarak kendimi olaylar karşısında çaresiz } \\
\text { hissediyorum. }\end{array}$ & & ,528 & & \\
\hline 14. Bir karar verirken başkalarının yol göstermesini isterim. & & ,514 & & \\
\hline $\begin{array}{l}\text { 20. Bir işe başlayacağım zaman o işi yapabilme konusunda } \\
\text { kaygılanırım. }\end{array}$ & & ,483 & & \\
\hline 21. Dünyaya erkek olarak gelmek isterdim. & & ,465 & & \\
\hline 25. Kadın olmaktan hoşlanmıyorum. & & ,368 & & \\
\hline 7. Kadının annelik görevi eğitiminden daha önemlidir. & & & ,794 & \\
\hline 8. Kadının aile huzuru eğitiminden önce gelir. & & & ,786 & \\
\hline 15. Kadınlar için iyi bir evlilik iyi bir eğitimden daha önemlidir. & & & ,655 & \\
\hline 22. Ailem/sevdiklerim için eğitimimi sürdürmekten vazgeçebilirim & & & ,637 & \\
\hline 9. Kadınlara daha az yasal haklar verilmelidir. & & & & ,725 \\
\hline $\begin{array}{l}\text { 16. Kadının eğitimli olması kadın / erkek ilişkilerini olumsuz } \\
\text { yönde etkiler. }\end{array}$ & & & &, 631 \\
\hline 31. Kadının yasal haklarını kullanması aile birliğini bozar. & & & & ,628 \\
\hline 28. Kadın zayıf olduğu için karar vermekte zorlanır. & & & & ,479 \\
\hline 30. Türkiye'de kadınlara verilen yasal haklar yeterlidir. & & & & ,457 \\
\hline
\end{tabular}

Yapılan analiz sonucunda ölçekteki maddelerin 4 boyut altında yer aldığı saptanmıştır. Ölçekteki maddelerin faktör yük değerlerinin ise 0,31 ile 0,79 arasında değiştiği gözlenmiştir. Ölçekteki maddelerden 
14 'ü .60 ve üstü faktör yük değerine sahiptir, diğer maddeler ise .30 ve üstü faktör yüküne sahiptir. Bu çerçevede 14 maddenin yapı ile yüksek ilişkili, 17 maddenin ise orta düzeyde ilişkili olduğunu söylemek mümkündür. Yapılan AFA sonucunda elde edilen alt boyutlara ait özdeğer ve açıkladıkları varyans oranları Tablo 2'de sunulmuştur.

Tablo 2. Kadın Psikolojik Güç Ölçeği Alt Boyutlarının Özdeğer ve Açıkladıkları Varyans Oranları

\begin{tabular}{clcll}
\hline Faktör & & Madde Sayısı & Özdeğer & Açıkladığı Varyans \\
\hline 1. & Güçlülük/Savunuculuk & 14 & 6,23 & 20,08 \\
2. & Benlik Saygısı & 8 & 2,86 & 9,22 \\
3. & Eğitme Yaklaşım & 4 & 2,37 & 7,63 \\
4. & Kısıtlayıcılık & 5 & 1,49 & 4,81 \\
& Toplam & 31 & 12,95 & 41,74 \\
\hline
\end{tabular}

Tablo 2'de görüldüğü gibi uygulanan AFA sonucunda elde edilen ölçek 31 madde ve 4 alt boyuttan oluşmaktadır. Alan yazın incelemesi ve boyutlarda yer alan maddeler dikkate alınarak bu boyutlar Güçlülük/savunuculuk, Kadın olarak benlik saygısı, Eğitime yaklaşım ve Kısıtlayıcılık olarak adlandırılmıştır.

Ölçekte 1. Alt boyut olan Güçlülük/Savunuculuk alt boyutunda 14 madde yer almaktadır. Bu boyutun özdeğeri 6,23 açıkladığı varyans ise 20,08 ' dir. Bu boyuttan alınabilecek minimum puan 14 maksimum puan ise 70'tir. Bu boyutta 1, 2, 3, 10, 11, 12, 17, 18, 19, 23, 24, 26, 27 ve 29'uncu maddeler yer almaktadır. Bu boyutta kadının kendisinin ve/veya kadınların haklarını savunması, gücünün ve güç kaynaklarının farkında olması, özgüven ve eşitlikçi tutumlarını ölçen maddeler yer almaktadır.

Ölçekte 2. Alt boyut olan Benlik Saygısı alt boyutunda 8 madde yer almaktadır. Bu boyutun özdeğeri 2,37 açıkladığ varyans ise 9,22'dir. Bu boyuttan alınabilecek minimum puan 8 maksimum puan ise 40 'tır. Bu boyutta 4, 5, 6, 13,14, 20, 21 ve 25'inci maddeler yer almaktadır. Bu boyutta yer alan maddeler kadın olarak kendi kimliğinden hoşnut olma, kendi yeteneklerine, karar verme gücüne ve kapasitesine güvenmeye yöneliktir.

Ölçekte 3. alt boyut olan Eğitime Yaklaşım alt boyutunda 4 madde yer almaktadır. Bu boyutun özdeğeri 22,37 açıkladığı varyans ise 7,63'tür. Bu boyuttan alınabilecek minimum puan 8 maksimum puan ise 20'dir. Bu boyutta 7, 8, 15 ve 22 'inci maddeler yer almaktadır. Bu boyutta yer alan maddeler ters puanlanmakta ve kadın eğitime yönelik yaklaşımını ölçmektedir.

Ölçeğin 4. Alt boyutu ise Kısıtlayıcılık alt boyutudur. Bu boyutta 5 madde yer almaktadır. Bu boyutun özdeğeri 1,49 açıkladığı varyans ise 4,81'dir. Bu boyuttan alınabilecek minimum puan 5 maksimum puan ise 25 'tir. Bu boyutta 9, 16, 18, 30 ve 31'inci maddeler yer almaktadır. Bu boyutta yer alan maddeler kadının kısıtlanmasını, cinsiyet eşitliğine karşı çıkışını ve geleneksel rollerde kalmasını savunan maddelerdir. Bu nedenle bu boyuttaki maddeler ters puanlanmaktadır.

Yapılan AFA sonucunda 31 maddeden oluşan bir ölçek formu ortaya çıkmıştır. Son formda 4, 5, 6, 7, 8, $9,13,14,15,16,20,21,22,25,28,30,31$ ve 21 . Maddeler ters puanlanmaktadır. Ölçeğin 4 alt boyutu birlikte varyansın \% 41,74'ünü açıklamaktadır. Sosyal bilimlerde geliştirilen ölçeklerde çok faktörlü desenlerde açıklanan varyansın \% 40 ile \% 60 arasında olması yeterli olarak kabul edilmektedir (Çokluk, Şekercioğlu ve Büyüköztürk, 2014). Bu ölçüt dikkate alındığında ölçeğin açıkladığı varyans kabul edilebilir sınırlar içerisindedir.

\section{Doğrulayıcı Faktör Analizi}

DFA'nın uygulanması için ilk etapta frekans tablosu aracılığıyla veri setindeki eksik değerler incelenmiş ve eksik değer olmadığı saptanmıştır. DFA'da test edilmesi gereken önemli bir varsayım da tek ve çok değişkenli aykırı değerlerdir. Tek değişkenli aykırı değerleri tespit etmek için gözlenen her bir değişkene ilişkin z değerinin +3.29 ile -3.29 arasında bir değer alması gerekmektedir (Tabachnick ve Fidell, 2001). Yapılan analizde veri setinde tek değişkenli aykırı değer olmadığı gözlenmiştir. Çok değişkenli aykırı değerlerin tespit edilebilmesi için ise Mahalanobis uzaklığı hesaplanmıştır. Bu uzaklığa ilişkin dağılım $\mathrm{x}^{2}$ de ki-kare dağılımı ile uyumludur. Yapılan analizde $\mathrm{X}_{(31, \mathrm{p}<0.001)}^{2}=61,098$ değeri üzerinde olan 38 gözlem çoklu aykırı değer olması nedeniyle analiz kapsamına alınmamıştır.

Açımlayıcı faktör analizi sonuçlarına göre ortaya çıkan ölçeğin yapısı birinci ve ikinci düzey doğrulayıcı faktör analiziyle (DFA) farklı bir çalışma grubundan toplanan veriler ile test edilmiştir. Yapılan 
birinci düzey DFA'da modifikasyon önerileri incelenmiş ve anlamsal olarak birbirleriyle ilişkili oldukları gözlenen ve aynı alt boyutlarda yer alan 1. ve 3. maddeler, 21. ve 25. maddeler, 30. ve 31. maddelerin hata kovaryansları ilişkilendirilmiştir. Aynı modifikasyon önerilerinin ikinci düzey DFA'da da olduğu gözlendiğinden aynı maddelerde ikinci düzey DFA'da da modifikasyon yapılmıştır. Çeşitli uyum indeksleri olmasına rağmen özellikle DFA'da model-veri uyumuyla ilgili ki-kare $(\chi 2)$, serbestlik derecesi ve manidarlık değeri, karşılaştırmalı uyum indeksi (comperative fit index; CFI), yaklaşık hataların ortalama karekökü (root mean squared error of approximation; RMSEA) ve Standarized Root Mean Square Residual (SRMR) değerlerinin raporlanması önerilmektedir (Kline, 2016). Bu çerçevede uygulanan birinci ve ikinci düzey DFA sonucunda elde edilen uyum iyiliği indeksleri Tablo 3 'te sunulmuştur:

Tablo 3. Doğrulayıcı faktör analizi için uyum indeksleri

\begin{tabular}{llllllll}
\hline$D F A$ & $x^{2}$ & $S d$ & $p$ & $\chi 2 / S d$ & RMSEA & CFI & SRMR \\
\hline Birinci Düzey & 997.99 & 425 & 0.00 & 2.35 & 0.058 & 0.91 & 0.07 \\
\hline İkinci Düzey & 1027.49 & 427 & 0.00 & 2,41 & 0.059 & 0.90 & 0.07 \\
\hline
\end{tabular}

Tablo 3 'te yer alan uyum indeksleri incelendiğinde $\chi 2 / \mathrm{Sd}$ değerinin birinci düzey için 2.35 ikinci düzey için ise 2.41 olduğu gözlenmektedir. Büyük örneklemlerde $\chi 2 / S d$ değerinin 3 'ün altında olmas1 mükemmel uyuma işaret etmektedir (Sümer, 2000; Çokluk, Şekercioğlu ve Büyüköztürk, 2012). Bu çerçevede $\chi^{2 / s d}$ oranının her iki düzey için de mükemmel uyum değeri verdiğini söylemek mümkündür. Aldığı değerin .08 ve aşağısında olması iyi uyuma işaret eden RMSEA (Tabachnick ve Fidell, 2001) değeri her iki düzey için de (.058 ve 0.59) bu kriteri taşımaktadır. CFI değeri incelendiğinde değeri birinci düzey için .91, ikinci düzey için .90 olduğu ve gözlenmiştir. CFI değerinin .90 ve yukarısında olması iyi uyuma işaret etmektedir (Sümer, 2000). Diğer taraftan .08 ve aşağısında olması iyi uyuma işaret eden SRMR değeri ise her iki düzey için de .07 olarak hesaplanmıştır. Bu çerçevede ortaya çıkan uyum indeksleri incelendiğinde model ve veri arasındaki uyumun yeterli olduğunu söylemek mümkündür.

Yapılan birinci düzey DFA ile ilgili sonuçlar Şekil 2’de sunulmuştur: 


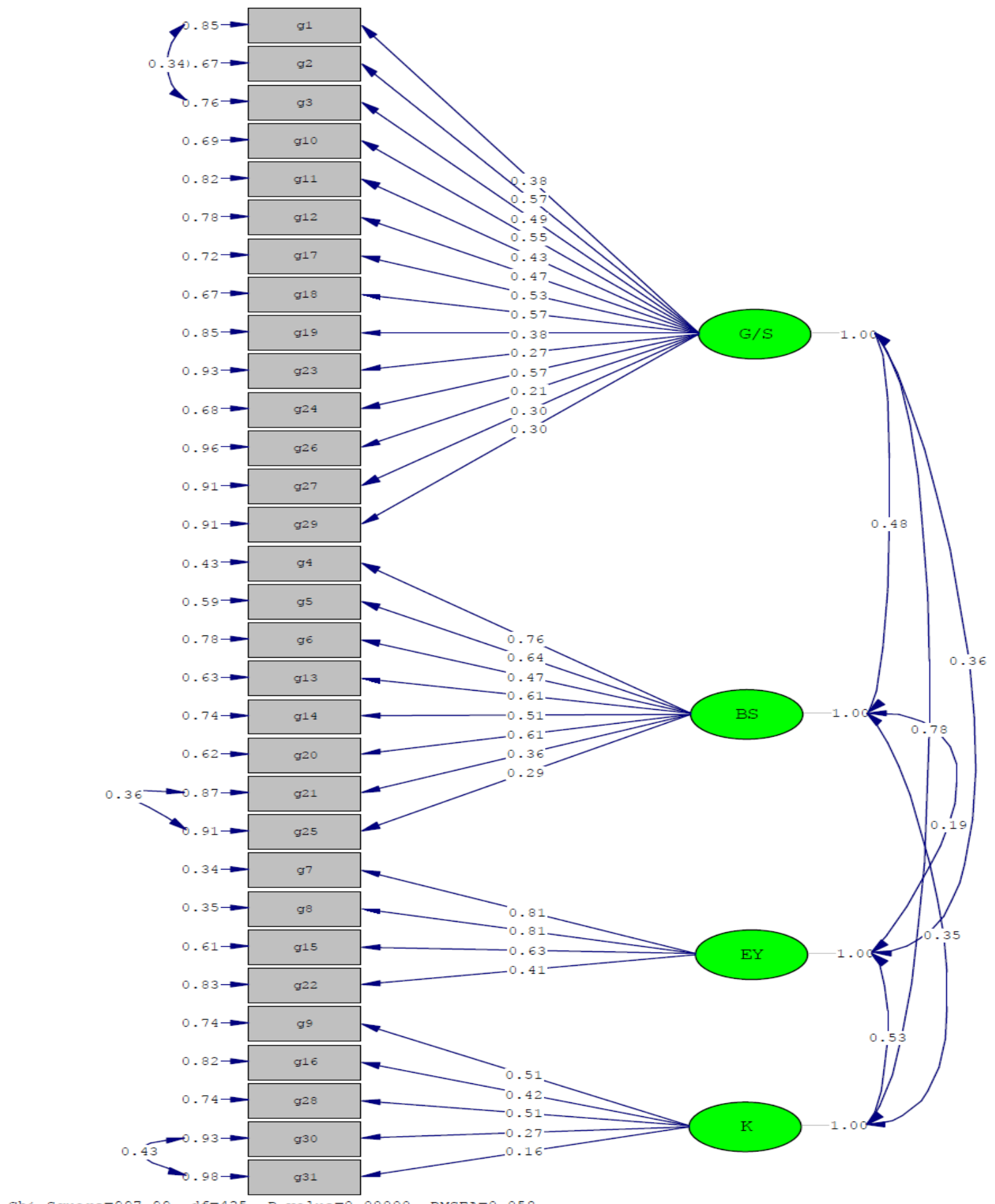

\section{Not: Bütün t değerleri anlamlıdır.}

G/S(Güçlülük/Savunuculuk), BS (Benlik Saygısı), EY(Eğitime Yaklaşım), K(Kısıtlayıcılık)

Şekil 2. Birinci Düzey DFA Standartlaştırılmış çözümleme değerleri sonuçlarına ait diyagram 
Yukarıda yapılan birinci düzey DFA'ya ilişkin standartlaştırılmış çözümleme değerlerine ait diyagram verilmiştir. Şekil 2'de görüldüğü gibi standartlaştırılmış çözümleme değerleri Güçlülük/Savunuculuk için 0.210.57 arasında; Benlik Saygısı için 0.29-0.76 arasında; Eğitime Yaklaşım için 0.41-0.81 arasında ve Kısıtlayıcılık için 0.16-0.51 arasında değişmektedir.

Tablo 4. Doğrulayıcı Faktör Analizine Ait Standartlaştırılmış Çözümleme, t ve $\mathrm{R}^{2}$ Değerleri.

\begin{tabular}{|c|c|c|c|}
\hline Madde No & $\begin{array}{l}\text { Standartlaştırılmış } \\
\text { Çözümleme Değerleri }\end{array}$ & t değerleri & $\overline{\mathrm{R}^{2}}$ \\
\hline 1 & 0.38 & 7.22 & 0.15 \\
\hline 2 & 0.57 & 11.36 & 0.33 \\
\hline 3 & 0.49 & 9.38 & 0.24 \\
\hline 4 & 0.76 & 15.98 & 0.57 \\
\hline 5 & 0.64 & 12.92 & 0.41 \\
\hline 6 & 0.47 & 9.06 & 0.22 \\
\hline 7 & 0.81 & 17.45 & 0.66 \\
\hline 8 & 0.81 & 17.33 & 0.65 \\
\hline 9 & 0.51 & 8.83 & 0.26 \\
\hline 10 & 0.55 & 10.94 & 0.31 \\
\hline 11 & 0.43 & 8.11 & 0.18 \\
\hline 12 & 0.47 & 9.03 & 0.22 \\
\hline 13 & 0.61 & 12.15 & 0.37 \\
\hline 14 & 0.51 & +2 & 0.26 \\
\hline 15 & +2 & +2 & 0.39 \\
\hline 16 & 0.42 & 7.26 & 0.18 \\
\hline 17 & 0.53 & 10.28 & 0.28 \\
\hline 18 & 0.57 & 11.33 & 0.33 \\
\hline 19 & 0.38 & 7.19 & 0.15 \\
\hline 20 & 0.61 & 12.30 & 0.38 \\
\hline 21 & 0.36 & 6.68 & 0.13 \\
\hline 22 & 0.41 & 7.81 & 0.17 \\
\hline 23 & 0.27 & 5.02 & 0.07 \\
\hline 24 & 0.57 & 11.28 & 0.32 \\
\hline 25 & 0.29 & 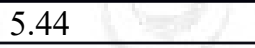 & 0.09 \\
\hline 26 & 0.21 & 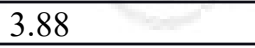 & 0.05 \\
\hline 27 & 0.30 & 5.57 & 0.09 \\
\hline 28 & 0.51 & 8.71 & 0.26 \\
\hline 29 & 0.30 & 5.64 & 0.09 \\
\hline 30 & 0.27 & 4.57 & 0.07 \\
\hline 31 & 0.16 & 2.62 & 0.03 \\
\hline
\end{tabular}

Standartlaştırılmış çözümleme değerleri her bir maddenin (gözlenen değişkenin) kendi gizil değişkeninin (ait olduğu faktörün) ne kadar iyi bir temsilcisi olduğuna ilişkin fikir veren değerlerdir. Tablodaki değerler incelendiğinde .30'un altında yük veren 5 madde $(23,25,26,30$ ve 31. Maddeler) olduğu gözlenmiştir. Ancak bu maddelere ait $t$ değerleri anlamlı olduğu, ölçeğin DFA uyum indeksleri kabul edilebilir sınırlar içerisinde olduğu ve maddeler kuramsal olarak da yapıyla uyumlu olduğu için bu maddelerin ölçekte tutulmasına karar verilmiştir.

Gizil değişkenlerin gözlenen değişkeni açıklama durumlarına ilişkin t değerleri 1.96'yı aştığında parametre tahminleri .05 düzeyinde ve 2.56 'yı aştı̆̆ında ise .01 düzeyinde manidar olduğu belirtilmektedir (Çokluk, Şekercioğlu ve Büyüköztürk, 2014). Maddelere ait t değerleri incelendiğinde bütün değerlerin 2.56'nın üzerinde olduğu gözlenmektedir. Bu nedenle bütün göstergelerin .01 düzeyinde manidar $\mathrm{t}$ değeri verdiği 
söylenebilir. Maddelerin regresyon katsayıları yani açıklayıcılık varyansları incelendiğinde ise, en yüksek katkıyı 7. maddenin (0.66) en düşük katkıyı 30. maddenin (0.02) sağladığı görülmektedir.

Yapılan analizler sonucunda ortaya çıkan alt boyutların Kadın Psikolojik Güç Ölçeği’nin Bileşenleri olup olmadığını belirlemek için çeşitli boyutları bir yapıyı ortak bir üst düzey faktörünün altına toplayarak yorumlama tekniği olan ikinci düzey DFA (Gould, 1987) kullanılmıştır. İkinci düzey DFA modellerinde ikinci düzeyi tanımlayabilmek için en az üç tane birinci düzey faktör gerektiği ve her faktörün altında da en az iki gösterge olması gerektiği belirtilmektedir (Çokluk, Şekercioğlu ve Büyüköztürk, 2012).

Yapılan ikinci düzey DFA'ya ait diyagram Şekil 3'te sunulmuştur: 


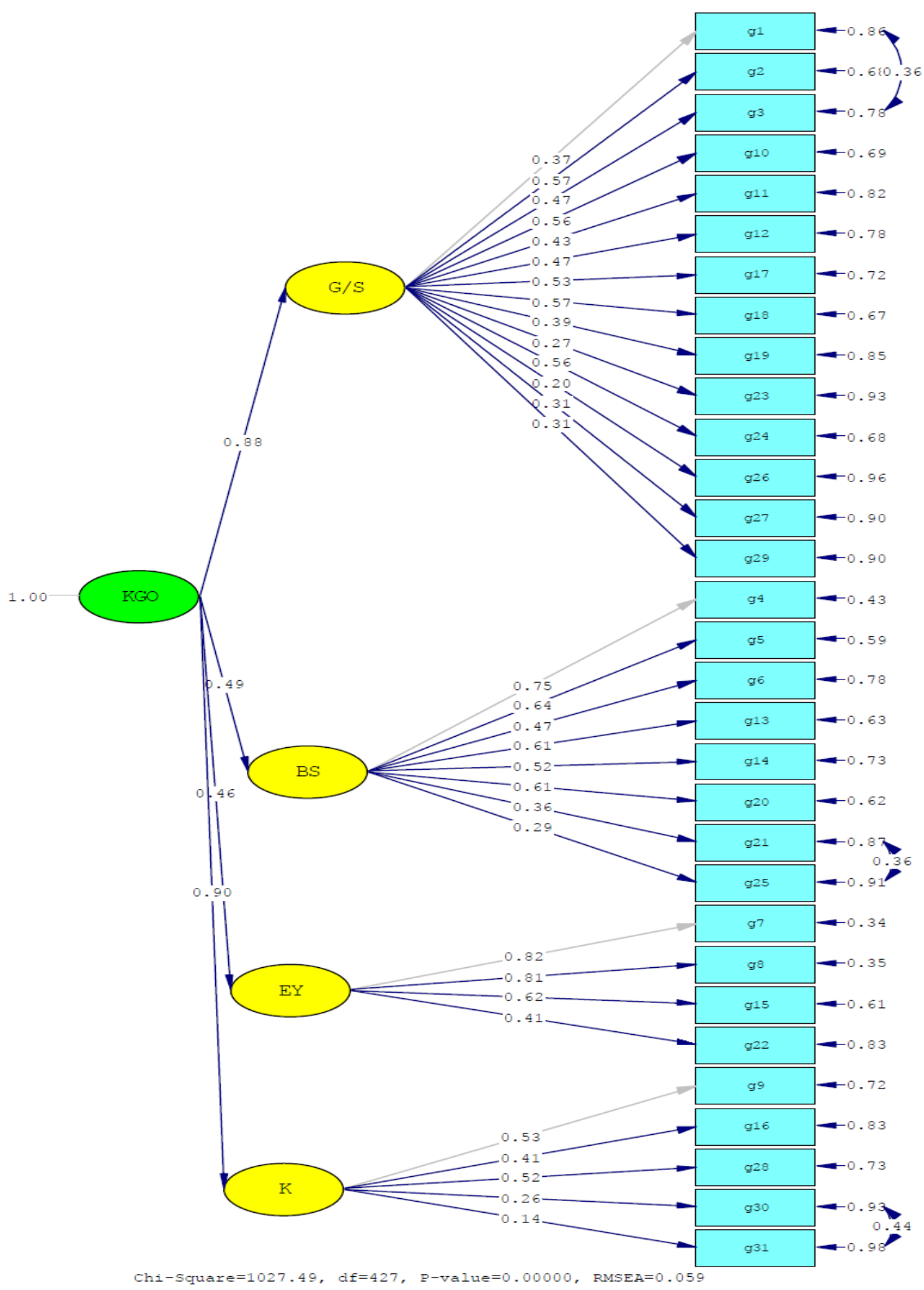

Not:

Bütün t değerleri anlamlıdır.

Şekil 3. İkinci Düzey DFA Standartlaştırılmış çözümleme değerleri sonuçlarına ait diyagram

Yapılan ikinci düzey DFA'ya ait standart çözümleme değerleri Şekil 3’te görülmektedir. Diyagram incelendiğinde Şekil 3’te görüldüğü gibi standartlaştırılmış çözümleme değerleri Güçlülük/Savunuculuk için 
0.20-0.57 arasında; Benlik Saygısı için 0.29-0.75 arasında; Eğitime Yaklaşım için 0.41-0.81 arasında ve Kısıtlayıcılık için 0.14-0.53 arasında değişmektedir. Bu değerler birinci düzey DFA ile oldukça yakındır. Ayrıca ikinci düzey DFA için de bütün t değerlerinin anlamlı olduğu görülmüştür.

Modeldeki birinci düzey gizil değişkenler (Güçlülük/Savunuculuk, Benlik Saygısı, Eğitime Yaklaşım ve Kısıtlayıcılık) ile ikincil düzey değişken olan Kadın Psikolojik Güç Ölçeği yapısı arasındaki yol katsayıları $(\lambda x)$, t ve $\mathrm{R}^{2}$ değerleri Tablo5'te verilmiştir.

Tablo 5. İkinci düzey DFA'ya ait Yol Katsayısı, t ve $\mathrm{R}^{2}$ değeri

\begin{tabular}{|l|l|l|l|l|}
\hline $\begin{array}{l}\text { İkinci Düzey } \\
\text { Değişken }\end{array}$ & Birinci Düzey Değişken & $\begin{array}{l}\text { Yol katsayısı } \\
(\mathbf{\lambda})\end{array}$ & $\mathbf{T}$ & $\mathbf{R}^{\mathbf{2}}$ \\
\hline \multirow{2}{*}{$\begin{array}{l}\text { Kadın Psikçeği } \\
\text { Ölojik Güç }\end{array}$} & 1. Güçlülük/Savunuculuk & .88 & 6.29 & .78 \\
\cline { 2 - 6 } & 2. Benlik Saygısı & .49 & 7.34 & .24 \\
\cline { 2 - 6 } & 3. Eğitime Yaklaşım & .46 & 7.08 & .21 \\
\cline { 2 - 6 } & 4. Kisıtlayııılık & .90 & 8.11 & .80 \\
\hline
\end{tabular}

Tablo 5'te de görüldüğü gibi Kadın Psikolojik Güç Ölçeği ile en yüksek ilişki (0.90) Kısıtlayıcılık alt boyutu, en düşük ilişki (0.46) ise Eğitime Yaklaşım alt boyutuna aittir. İkinci düzey DFA için elde edilen uyum iyiliği değerlerinin de $(\chi 2 / \mathrm{df}=2.41, \mathrm{RMSEA}=.059, \mathrm{CFI}=.90, \mathrm{SRMR}=.07)$ birinci düzey DFA ile benzer olarak kabul sınırları içerisinde olduğu saptanmıştır. İkinci düzey değişken ile tüm birinci düzey yapılar arasındaki ilişkinin anlamlı $(\mathrm{p}=.00)$ olduğu saptanmıştır. Modeldeki ikinci düzey değişkendeki varyansı birinci düzey değişkenlerden sırasıyla Kısıtlayıcılık (\%77), Güçlülük/Savunuculuk (\%78), Benlik Saygısı (\%24) ve Eğitime Yaklaşım (\%21) açıklamaktadır. Bu sonuçlara göre Güçlülük /Savunuculuk, Benlik Saygısı, Eğitime Yaklaşım ve Kısıtlayıcılık boyutlarının Kadın Psikolojik Güç Ölçeği’nin bileşenleri olduğu doğrulanmıştır.

\section{Kadın Psikolojik Güç Ölçeğinin Güvenirliği}

Ölçeğin güvenirliği için Cronbach Alpha iç tutarlılık katsayısı ve test-tekrar test, tekniklerinden yararlanılmıştır. Ayrıca ölçeğin alt boyutlarının birbirleri ve ölçek toplam puanlarıyla korelasyonu incelenmiştir. Test-tekrar test uygulaması için öncelikle ölçek 67 kişilik bir gruba uygulanmış ve iki hafta arayla tekrar uygulanmıştır. Ölçeğin toplamının ve alt boyutlarının Cronbach alpha iç tutarlılık katsayıları ile test tekrar test korelasyonları Tablo 5'te sunulmuştur:

Tablo 6. Kadın Psikolojik Güç Ölçeğine İlişkin Cronbach Alpha ve Test Tekrar Test Sonuçları

\begin{tabular}{lcc}
\multicolumn{1}{c}{ Faktör } & Cronbach Alfa & Test Tekrar Test \\
\hline Güçlülük/Savunuculuk & .80 & .65 \\
Benlik Saygısı & .70 & .72 \\
Eğitime Yaklaşım & .80 & .79 \\
Kisıtlayıcılık & .64 & .63 \\
Ölçek (Toplam) & .84 & .75 \\
\hline
\end{tabular}

Tablo 6'da görüldüğü gibi yapılan analizlerde Kadın Psikolojik Güç Ölçeği toplamı için Cronbach Alpha katsayısı .84, Güçlülük/Savunuculuk alt boyutu için .80, Benlik Saygısı alt boyutu için .70, Eğitime Yaklaşım alt boyutu için .80, ve Kısıtlayıcılık alt boyutu için .64 olarak hesaplanmıştır. Cronbach Alpha değeri $\geq$ 0.90 olduğunda mükemmel, $0.70 \leq \alpha<0.90$ olduğunda iyi, $0.60 \leq \alpha<0.70$ arasında olduğunda kabul edilebilir, $0.50 \leq \alpha<0.60$ olduğunda Zayıf ve .5 ve altında olduğunda ise kabul edilemez olduğu belirtilmektedir (George ve Pallary, 2003). Bu çerçevede elde edilen bulgular incelendiğinde Cronbach Alpha iç tutarlılık katsayısı ölçek toplam puanı, Güçlülük/Savunuculuk, Benlik Saygısı ve Eğitime Yaklaşım alt boyutları için iyi kategorisinde; Kısıtlayıcılık alt boyutu için ise kabul edilebilir kategorisinde olduğunu söylemek mümkündür.

Yapılan analizlerde ölçeğin toplamı için test tekrar test güvenirlik katsayısı .75; Güçlülük/Savunuculuk alt boyutu için .65; Benlik Saygısı alt boyutu için .72; Eğitime Yaklaşım alt boyutu için .79 ve Kısıtlayıcılık alt boyutu için ise .63 olarak hesaplanmıştır. Psikolojik testler için test-tekrar test korelasyon katsayıs1 .40-.59 arasında orta, .60.- .74 iyi .75 ve üstü ise mükemmel olarak değerlendirilmektedir (Cicchetti, 1994). Bu çerçevede elde edilen sonuçlar değerlendirildiğinde test-tekrar test korelasyon katsayıları ölçek toplam puanı ve 
Eğitime Yaklaşım alt boyutu için mükemmel, Benlik Saygısı Alt Boyutu, Güçlülük/Savunuculuk alt boyutu ve Kısıtlaıcılık alt boyutu için ise iyi kategorisindedir.

Geçerli olan bir ölçekte alt boyutlar arasındaki ilişkinin ne aşırı derecede yüksek ne de aşırı derecede düşük olmaması istendik bir durumdur. Ayrıca da bu korelasyonların istatistiksel olarak anlamlı olması gerekmektedir (Gündüz ve Coşkun, 2012). Bu temelde ölçeğin alt boyutları ve bu alt boyutların ölçek toplam puanıyla korelasyonuna ilişkin analizler yapılmış ve elde edilen bulgular Tablo 7'de sunulmuştur.

Tablo 7. Kadın Psikolojik Güç Ölçeği toplam puan ve alt boyutları arasındaki ilişkiyi gösteren korelasyon değerleri.

\begin{tabular}{|c|c|c|c|c|c|}
\hline Boyutlar & 1 & 2 & 3 & 4 & 5 \\
\hline Güçlülük/Savunuculuk & - & & & & \\
\hline Benlik Saygısı &, $29^{* *}$ & - & & & \\
\hline Eğitime Yaklaşım &, $24^{* *}$ &, $32^{* *}$ & - & & \\
\hline Kisitlayicilık &, $31^{* *}$ &, $29^{* *}$ &, $43^{* *}$ & - & \\
\hline Ölçek (Toplam) &, $74^{* *}$ &, $73^{* *}$ & $65^{* *}$ &, $62^{*}$ & - \\
\hline
\end{tabular}

**.Korelasyonlar .01düzeyinde anlamlıdır (2-tailed).

Tablo 7'de de görüldüğü gibi Güçlülük/Savunuculuk alt boyutunun ölçek toplam puanıyla korelasyonu . 74, Benlik Saygısı alt boyutunun ölçeğin toplam puanıyla korelasyonu .73, Eğitime Yaklaşım alt boyutunun ölçeğin toplam puanıyla korelasyonu .65; Kısıtlayıcılık alt boyutunun ölçeğin toplam puanıyla korelasyonu .62 olarak saptanmıştır. Geçerli bir testte ölçeğin alt boyutları ile toplam puanı arasında anlamlı korelasyonlar olması gerektiği belirtilmekte (Tavşancıl, 2010) ve bunun ölçeğin bir yapı oluşturduğuna kanıt olduğu (Otrar ve Argın, 2015) belirtilmektedir. Bu çerçevede elde edilen bulguların ölçeğin geçerlik ve güvenirliğine katkıda bulunduğu söylenebilir.

Tablo 7 incelendiğinde ölçeğin alt boyutları arasında düşük ve orta düzeyde fakat anlamlı ilişsiler olduğu gözlenmektedir. Ölçeği oluşturan boyutların aralarındaki ilişkinin çok uç değerler arasında olmadığ görülmektedir. Boyutlar arası ilişkilerin istendik düzeyde olmasının ölçeğin güvenirliğinin ayrı bir göstergesi olduğunu söylemek mümkündür.

\section{Ölçeğin Puanlanması ve Yorumlanması}

Kadın Psikolojik Güç Ölçeği 31 maddeden ve 4 alt boyuttan oluşmaktadır. Ölçekte 4, 5, 6, 7, 8, 9, 13, 14, 15, 16, $20,21,22,25,28,30$ ve 31 . Maddeler ters diğer maddeler ise düz puanlanmaktadır. Ölçekte 14 madde Güçlülük/Savunuculuk, 8 madde Benlik Saygısı, 4 madde Eğitime Yaklaşım, 5 madde ise Kısıtlayıcılık alt boyutunda yer almaktadır. Ölçek 5'li Likert tipindedir (5= Tamamen Katılıyorum, 1= Kesinlikle katılmıyorum). Ölçek hem toplam puan hem de alt boyutlar bazında puan vermektedir. Ölçekten alınan yüksek puan kadının psikolojik güç algısının yüksek olduğunu göstermektedir.

\section{Tartışma, Sonuç ve Öneriler}

$\mathrm{Bu}$ araştırmanın amacı, kadınlarda güçlenmenin önemli bir boyutu olan ve güçlenmenin diğer yönlerini de doğrudan etkileyen psikolojik güçlenmenin ölçülmesine yönelik bir ölçme aracının geliştirilmesidir. Geliştirilen ölçme aracının geçerlik ve güvenirlik çalışmaları kapsamında; kapsam geçerliği, açımlayıcı faktör analizi, doğrulayıcı faktör analizi, Cronbach Alpha iç tutarlılık katsayıları, test tekrar test güvenirliği ve ölçeğin alt boyutlarının birbirleri ve ölçeğin toplam puanıyla olan korelasyonları hesaplanmış ve elde edilen sonuçlar geliştirilen ölçeğin geçerlik ve güvenirlik özelliklerinin kabul edilebilir sınırlar içerisinde olduğunu ortaya koymuştur.

Ölçeğin birinci alt boyutu olan ve Güçlülük/Savunuculuk olarak adlandırılan alt boyutun toplumsal cinsiyet rollerine karşı çıkma, kadın olarak kendisinin ve diğer kadınların haklarını savunma, kadın olarak kendisini özgüvenli, eşit ve yeterli hissetmeye yönelik maddelerin yer aldığı gözlenmiştir. Güçlenmenin kişinin öz güveni ve bilincini kullanarak kaynaklara erişme veya geleneksel ideolojiyi değiştirme önündeki dış engellerin üstesinden gelmesini sağlayan içsel bir dönüşümü ifade ettiği (Sen ve Batliwala, 2000) düşünüldüğünde Güçlülük/Savunuculuk boyutunda yer alan maddelerin buna uygun bir içerikte olduğu gözlenmektedir.

Ölçeğin ikinci boyutu benlik saygısı alt boyutudur. Benlik saygısı, benlik algısı ve onurun güçlenmesine işaret eden bu boyut kadın olarak kendi benliğinden ve kimliğinden memnun olma, karar verme ve başarabilme 
gücüne güvenmeyi ölçen maddelerden oluşmaktadır. Benlik saygısı, bireylerin kendisine kendi değerlerine ilişkin kişisel yargılarına atıfta bulunmaktadır (Coopersmith, 1967). Benlik saygısının psikolojik güçlülüğün temelini oluşturan özelliklerden biri olduğu belirtilmektedir (Spreitzer, 1995; Stromquist, 1995). Özellikle kişisel ve psikolojik güçlenmenin özgüven, benlik saygısı, kontrol duygusu, daha geniş bir bağlamda benlik algısı ve onuru güçlendirmeye destek olan dönüşüm süreçlerinin temelini oluşturan temel öğeler kümesi olarak tanımlandığ1 (Rowlands, 1997) göz önünde bulundurulduğunda bu boyutun psikolojik güçlenmenin önemli bir yönünü oluşturduğu düşünülmektedir.

Ölçeğin üçüncü boyutu eğitime yaklaşım alt boyutudur. Bu boyutta yer alan maddeler kadının eğitime toplumsal cinsiyet rolleriyle uyumlu bir yaklaşıma sahip olup olmadığını ölçen ve ters olarak puanlanan maddelerden oluşmaktadır. Eğitimin kadınların toplumdaki konumlarını değiştirmenin en güçlü yollarından biri olduğu ve kadınlarda bilişsel, psikolojik, politik ve ekonomik boyutlarda güçlenmeyi geliştirme potansiyeline sahip olduğu (Stromquist, 2012) düşünüldügünde bu boyutun kadının güçlenmesinde önemli bir yere sahip olduğunu söylemek mümkündür.

Ölçeğin dördüncü alt boyutu Kısıtlayıcılık alt boyutudur. Bu boyutta yer alan maddeler kadının kısıtlanmasını, geleneksel rollerde kalmasını savunan ve cinsiyet eşitliğine karşı çıkan ifadelerden oluşan maddelerdir. $\mathrm{Bu}$ nedenle bu boyuttaki maddeler ters puanlanmaktadır. Psikolojik veya kişisel güçlenmenin kadının kültürden veya bağlamdan kaynaklanan toplumsal cinsiyet rollerinden çıkabilme (Francina ve Joseph, 2013) gücüne vurgu yaptığı düşünüldüğünde geleneksel tutumlara sahip olup olmamanın da kadının güçlenmesini ölçebileceği düşünülmektedir.

Sonuç olarak bu çalışma kapsamında kadınlarda psikolojik gücü ölçmeye yönelik geçerli ve güvenilir bir ölçme aracı geliştirilmiştir. Geliştirilen ölçme aracının kadınlarda psikolojik gücü ve güçlenmeye ihtiyaç duyulan noktaları belirlemede kullanılabilecek bir araç olduğu öngörülmektedir.

Gelişmekte olan ülkeler kategorisinde yer alan Türkiye'de kadınlar toplumsal cinsiyet eşitliği açısından oldukça dezavantajlıdır. 2020 yılı aralık ayında yayınlanan, 153 ülkeyi kapsayan ve ülkelerde ekonomik katılım ve fırsat, eğitime katılım, sağlık, sağ kalım ve politik güçlenme alanlarının ele alındığı "Küresel Cinsiyet Eşitliği Uçurum Raporu"na göre Türkiye 144 ülke arasında 130. Sırada yer almaktadır (Global Gender Gap, 2020). Bu durum Türkiye'de kadınların güçlenmesinin toplumsal cinsiyet eşitliğini sağlama konusundaki aciliyetini göstermektedir. Kişinin kendi durumunu değiştirebileceği inancı ve değişimi hedefleyen faaliyetlere katılma isteği olmadığı sürece güçlenmesinin zor olduğu, bu nedenle psikolojik güçlendirmedeki eksikliğinin diğer tüm güçlendirme biçimlerinin etkisini kıracağı (Francina ve Joseph, 2013) göz önünde bulundurulduğunda demografik verilerin ötesine geçerek psikolojik gücü ölçen bir ölçme aracının bu alanda var olan önemli bir eksikliği giderdiği düşünülmektedir.

$\mathrm{Bu}$ çalışma farklı yaş gruplarından kadınların katılımıyla gerçekleştirilmiştir. Sadece üniversite öğrencileri veya belli bir yaş grubunda değil bütün gruplarda geliştirilmiş olması bu ölçeğin avantajlarından biridir. Bu temelde bu ölçeğin bütün yaş gruplarındaki kadınlara uygulanabileceği düşünülmektedir. Ayrıca literatürde kadınlarda güçlenmeyi ölçen diğer ölçme araçlarının başka boyutlara odaklandığı (Bakshi ve ark.; Spreitzer, 1995; Üner ve Fırat, 2010; Schuler, Hashemi ve Riley,1997; Baydur ve Uçan, 2016) gözlendiği ve kadınlarda psikolojik güçlenmeyi ölçen başka bir ölçme aracına rastlanmadığı için bu ölçeğin farklı dillere de çevrilerek kullanılmasının faydalı olacağı öngörülmektedir.

Kadınlarda psikolojik güçlenmeyi doğrudan ölçen bir ölçeğe Türkçe literatürde rastlanmadığından ölçüt ölçek geçerlilik çalışması yapılamamıştır. Bu durumu araştırmanın bir sınırlılığı olarak ele almak mümkündür. $\mathrm{Bu}$ konuda ileride yapılacak çalışmalarda ölçeğin psikolojik güç, benlik saygısı, psikolojik dayanıklılık, psikolojik iyi oluş, toplumsal cinsiyet tutumları, vb. değişkenlerle olan ilişkilerinin incelendiği çalışmaların yapılmasının yararlı olacağı öngörülmektedir. Bu çalışmaların hem psikolojik gücün bu değişkenlerle olan ilişsilerini belirlemek hem de geliştirilen ölçme aracının ölçme gücünü de ortaya koyması açısından önemli olduğu düşünülmektedir.

$\mathrm{Bu}$ araştırma; genel popülasyondan kadınlar ile gerçekleştirilmiştir. Özellikle katılımcıların büyük çoğunluğu eğitim düzeyi yüksek olan kadınlardır. Bu grubun eğitim, bilgisayar, internet, telefon vb. araçlara yani bu güce zaten halihazırda ulaşabildiği düşünüldüğünde ölçeğin bu olanaklara sahip olmayan kadınlarda da geçerlik ve güvenirliğinin test edilmesinin faydalı olacağı düşünülmektedir. 


\section{Kaynakça}

Bakhshi, F., Shojaeizadeh, D., Sadeghi, R., Nedjat, S., Taghdisi, M. H., \& Laverack, G. (2017). Psychological empowerment of NGO women in Iran: Designing a tool. Electronic physician, 9(9), 5270-5278.

Baydur, H., \& Uçan, G. (2016). Kadınların güçlendirilmesi ölçeği'nin türkçe geçerlilik ve güvenilirlik çalışması: Manisa örneği. Journal of Society \& Social Work, 27(2), 7-28.

Bhat, R. A. (2015). Role of education in the empowement of Women in India. Journal of Education and Practice, 6(10), 188-191.

Büyüköztürk, Ş. (2010). Sosyal bilimler için veri analizi el kitabı: Istatistik, araştırma deseni, spss uygulamaları ve yorum. Ankara, Pegem Akademi.

Conger, J. and Kanungo, R., (1988). "The empowerment process: integrating theory and practice," Academy of Management Review, 13(3): 471-482.

Cicchetti, D.V. (1994). Guidelines, criteria, and rules of thumb for evaluating normed and standardized assessment instruments in psychology. Psychological Assessment, 6(4), 284-290.

Çokluk, Ö., Şekercioğlu, G., Büyüköztürk, Ş. (2010). Sosyal bilimler için çok değişkenli istatistik: Spss ve Lisrel uygulamaları. Ankara, Pegem Akademi.

Francina, P. X., \& Joseph, M. V. (2013). Women empowerment: The psychological dimension. Rajagiri Journal of Social Development, 5(2), 163-176.

George D, \& Mallery P. (2003). SPSS for Windows step by step: A simple guide and reference. 11.0 update (4th ed.). Boston: Allyn \& Bacon.

Gould, S. J. (1987). Second order confirmatory factor analysis: An example. In Proceedings of the 1987 Academy of Marketing Science (AMS) Annual Conference (pp. 488-490). $\quad$ Springer, Cham.

Gündüz, Y. ve Coşkun, Z. S. (2012). Öğrenci algısına göre öğretmen etik değerler ölçeğinin $\quad$ geliştirilmesi: Geçerlik ve güvenirlik çalışması. Ahi Evran Üniversitesi Kırşehir Eğitim Fakültesi Dergisi, 13(1), 111-131.

Huis, M. A., Hansen, N., Otten, S., \& Lensink, R. (2017). A three-dimensional model of women's empowerment: Implications in the field of microfinance and future directions. Frontiers in psychology, $8,1678$.

Kawaguchi, L., Fouad, N. A. M., Chiang, C., Elshair, I. H. H., Abdou, N. M., El Banna, S. R., \& Aoyama, A. (2014). Dimensions of women's empowerment and their influence on the utilization of maternal health services in an Egyptian village: a multivariate analysis. Nagoya journal of medical science, 76(1-2), 161.

Lorber, J. (1994). Paradoxes of gender. New Haven: Yale University Press.

Malhotra, A., Schuler, S. R. \& Boender, C. (2002) Measuring Women's Empowerment as a Variable in International Development. Washington, DC: The World Bank.

Moghadam, V. M., \& Senftova, L. (2005). Measuring women's empowerment: participation and rights in civil, political, social, economic, and cultural domains. International Social Science Journal, 57(184), 389412. 
Murphy-Graham, E. (2010). And when she comes home? Education and women's empowerment in intimate relationships. International Journal of Educational Development, 30(3), 320-331.

Otrar, M., \& Argın, F. S. (2015). Öğrencilerin sosyal medyaya ilişkin tutumlarını belirlemeye yönelik bir ölçek geliştirme çalışması. Eğitim ve Öğretim Araştırmaları Dergisi, 4(1), 391-403.

Pillai, J. K. (1995). Women and empowerment. New Delhi: Gyan Publishing House.

Pradhan,B. (2003). Measuring empowerment: a methodological approach. Development, 46(2), 51-57.

Rowlands, J. (1997).Questioning Empowerment: Working with Women in Honduras. Oxfarm, UK: Oxford.

Schuler, S. R., Hashemi, S. M., \& Riley, A. P. (1997). The influence of women's changing roles and status in Bangladesh's fertility transition: Evidence from a study of credit programs and contraceptive use. World Development, 25(4), 563- 575.

Sen, G. and S. Batliwala (2000) 'Empowering Women for Reproductive Rights', in Harriet B. Pressure and G. Sen (eds) Women's Empowerment and Demographic Processes. New York: Oxford University Press.

Spreitzer, G. M. (1995). Psychological empowerment in the workplace: Dimensions, measurement, and validation. The Academy of Management Journal, 38(5), 1442-1465.

Stevens, J. (2002). Applied multivariate statistics for the sciences. Hillsdale, NJ: Laurence

Erlbaum Associates.

Sümer, N. (2000). Yapısal eşitlik modelleri. Türk Psikoloji Yazıları, 3(6), 49-74.

Tabachnick G.B, Fidel S.L. (2015) Çok değişkenli istatistiklerin kullanımı, (Çev. Ed. Mustafa Baloğlu), Nobel Yayıncılık, Ankara.

Tavşancıl, E. (2010). Tutumların ölçülmesi ve SPSS ile veri analizi. Nobel Yayıncılık, Ankara.

UNFIEM, Progress of the World Women, UNIFEM Biennial report, accessed at www.undp.org/unifem/progressww/2000.

Üner, S., \& Turan, S. (2010). The construct validity and reliability of the Turkish version of Spreitzer's psychological empowerment scale. BMC public health, 66(1), 84-91. 